\title{
Derleme/Review \\ Mikroorganizma Taşıyıcısı Yenilebilir Filmler ve Kaplamalar
}

\author{
Ekin DİNÇEL KASAPOĞLU ${ }^{1 *}$, Fatih TÖRNÜK² \\ ${ }^{1}$ İstanbul Aydın Üniversitesi, ABMYO, Gıda Teknolojisi Programı, 34295, Küçükçekmece, İstanbul \\ ${ }^{2}$ Yıldız Teknik Üniversitesi, Kimya-Metalürji Fakültesi, Gıda Mühendisliği Bölümü, 34210, Esenler, İstanbul \\ *e-posta: ekindincel@aydin.edu.tr; Tel: +90 (444) 1428-41053
}

Öz: Yenilebilir özellikteki karbonhidrat, protein ve lipitlerin kullanımı ile üretilen yenilebilir film ve kaplamalar, gıdaların yüzeyine ince bir film olarak uygulanmakta olup gıdaların korunmasında, dağıtım ve pazarlanmasında önemli bir yere sahiptirler. Yenilebilir filmlerin en önemli işlevi, ürünü mekanik hasar ile fiziksel, kimyasal ve mikrobiyolojik bozulmalara karşı korumaktır. Yenilebilir film ve kaplamalar üzerinde son yıllarda çalışılan en önemli konulardan birisi, bunların mikroorganizma taşıııcısı olarak kullanılma potansiyellerinin ortaya konulmasıdır. Mikroorganizma taşıyıcısı yenilebilir film ve kaplama uygulamalarında genellikle probiyotik bakteriler ve antagonistik mayalar kullanılmaktadır. Probiyotik taşıyıcısı filmler, fonksiyonel bir gıda üretiminin yanı sıra antimikrobiyel özellikleri ile gıdaların kontaminasyondan korunması ve raf ömürlerinin uzatılmasını da sağlamaktadırlar. Antagonist mayalar ise, daha çok meyve ve sebzelerde kullanılmakta ve onların hasat sonrası çürümelerinin geciktirilmesi ile dayanımlarının artırılmasında biyokontrol ajanı olarak rol oynamaktadır. $\mathrm{Bu}$ çalışmada; yenilebilir filmler ve kaplamaların üretimi ile bunların üretiminde kullanılan materyaller hakkında bilgi verilmekte ve mikroorganizma taşıyıcısı yenilebilir filmler hakkında yapılmış olan çalışmalar özetlenmektedir.

Anahtar kelimeler: Bakteri, Gıda ambalajlama, Gıda raf ömrü, Maya, Yenilebilir film ve kaplama

\section{Microorganism Incorporated Edible Films and Coatings}

\begin{abstract}
Edible films and coatings produced by the use of edible carbohydrates, proteins and lipids are applied as a thin film on the surface of foodstuffs and have an important role on the protection, distribution and marketing of foods. The most significant function of edible films is to protect the product against mechanical damage and physical, chemical and microbiological spoilage. In recent years, the focus is on edible films and coatings that reveal their potential as carriers of microorganisms. In general, probiotic bacteria and antagonistic yeasts are incorporated in carrier edible films and coatings of living microorganisms. Probiotic carrier films provide production of functional foods as well as preservation from microbial contamination and extension of shelf life due to their antimicrobial activity. Antagonist yeasts are mainly used for fruit and vegetables and play role as biocontrol agent in delaying postharvest decay and increasing their stability. In this study; information on the production of edible films and coatings and the materials used in their production was given. Furthermore, the studies conducted on microorganism incorporated edible films and coatings were summarized.
\end{abstract}

Keywords: Bacteria, Food packaging, Food shelf life, Yeast, Edible film and coating

\section{Giriş}

Ambalaj materyali; gıdaların oksijen, 1şık, 1sı, kimyasal etki, mikroorganizma ve fiziksel etki gibi çevresel faktörlerden korunmasını sağlayan, onu nihai tüketiciye kadar taşıyan, nakliyesi ile dağıtımına yardımcı olan ve tüketici ile gıda arasında iletişim kuran bir araç olarak tanımlanmaktadır (Gerarg ve Liyland 1996). Gıdaların ambalajlanmasında yaygın olarak kâğıt, metal, cam ve plastikten üretilen ambalaj materyalleri kullanılmaktadır. Ambalaj materyali seçiminde gıda maddelerinin kimyasal bileşimine uygun ve çevre kirliliği oluşturmayan geri dönüşümlü malzemelerin kullanımı son zamanlarda büyük önem kazanmıştır. Özellikle tüm dünyada artan plastik ambalaj materyali kullanımı, ambalaj atıklarının geri dönüşümü ve çevre sağlığı üzerinde önemli sorunlara neden olmaktadır (Avella ve ark. 2005). Bu nedenle, plastiklerin doğada daha hızlı ayrışmasını sağlayan, plastik kullanımını azaltan ve biyobozunur ve/veya yenilebilir özellikli ambalaj materyallerinin kullanımını arttırmaya yönelik araştırmalar yoğunlaşmıştır (Abdul Khalil ve ark. 2006).

Gıdalarda kalite kayıplarını önlemek ve raf ömrünü uzatmak amacıyla gıdanın yüzeyine uygulanabilen ya da gıda bileşenleri arasında oluşmuş, ince tabakalı, gıdayla birlikte tüketilebilen, sentetik olmayıp doğal kaynaklardan elde edilen maddelere "yenilebilir film ve kaplamalar" denilmektedir (Galus ve Kadzińska 2015). Konvansiyonel 
plastiklerin yerine kullanılan filmlerin hem yenilebilir hem de biyobozunur olmaları istenmektedir. Çoğu protein ve karbonhidrat, yenilebilir özellikte olduğu için yenilebilir film ve kaplama üretiminde matris olarak kullanılabilmekte ise de (Krochta 2002) her biyobozunur film yenilebilir değildir. Yenilebilir filmler, bileşimleri ve kompozisyonları bakımından gıda saflığında olmalıdır. Yenilebilir film formülasyonlarında matrisin yanı sıra plastikleştirici ve diğer katk1 maddeleri de bulunabilmektedir (Otoni ve ark. 2017).

Yenilebilir film ve kaplamaların en önemli görevleri; oksijen, karbondioksit ve lipit geçişlerini kontrol altında tutmak, tat ve aroma maddelerinin kaybını azaltmak, antioksidanları, antimikrobiyel maddeleri, pigmentleri, esmerleşme reaksiyonlarını durduran iyonları ve vitaminleri ürünün içerisinde tutmak ve gıda kalitesi ile raf ömrünü geliştirmektir (Guimarães ve ark. 2018). Son yıllarda, yenilebilir film ve kaplamalara canlı mikroorganizmaların ilavesi ile filme fonksiyonellik kazandırılarak gıda endüstrisine yeni fırsatlar sunulmasına yönelik çalışmalar yapılmaktadır. Bu derlemede, mikroorganizma taşıyıcısı olarak yenilebilir film ve kaplamaların kullanımına yönelik yapılmış çalışmalar hakkında bilgi verilmesi amaçlanmıştır.

\section{Yenilebilir Film ve Kaplama Üretiminde Kullanılan Materyaller}

Yenilebilir film ve kaplamalar, yenilebilir özellikteki biyopolimerler ile gıda saflığındaki katkı maddeleri kullanılarak üretilmektedirler. Film oluşturucu biyopolimerler; polisakkaritler (kitosan, pullulan, pektin, aljinat, nişasta vs.), proteinler (mısır zeini, jelatin, buğday gluteni, peyniraltı suyu proteini vs.), lipitler (vakslar, parafinler, şellak reçineleri, asetogliseritler vs.) ya da bunların kombinasyonları olabilmektedir (Hassan ve ark. 2018). Şekil 1'de gida uygulamalarında kullanılma potansiyeline sahip biyopolimerlerin sınıflandırılması görülmektedir. Proteinler, film üretiminde yaygın olarak kullanılan polimerlerdir. Proteinleri diğerlerinden ayıran en önemli özellikleri; konformasyonel denatürasyon, elektrostatik yüklerin varlığı ve amfifilik yapılarıdır (Han 2014). Karbonhidratlar, 20 farklı amino asitten oluşan proteinlere kıyasla daha basit monomer yapısına sahiplerdir. Bununla birlikte, karbonhidratların kimyasal yapısı daha komplike olup proteinlerden çok daha yüksek molekül ağırlıkları vardır. Birçok karbonhidrat nötral olsa da bazı gamlar negatif yüklüdür. Aljinat, karboksimetil selüloz ve pektin gibi bazı karbonhidratlar asidik koşullarda çok daha farklı reolojik özellikler göstermektedirler (Nur Hannani ve ark. 2014). Yenilebilir film uygulamalarında kullanılan lipitler ise genellikle oda sıcaklığında katı haldedirler ve hidrofobik özellikleri ile suya karşı yüksek direnç göstermekte ve düşük yüzey enerjisi taşımaktadırlar.

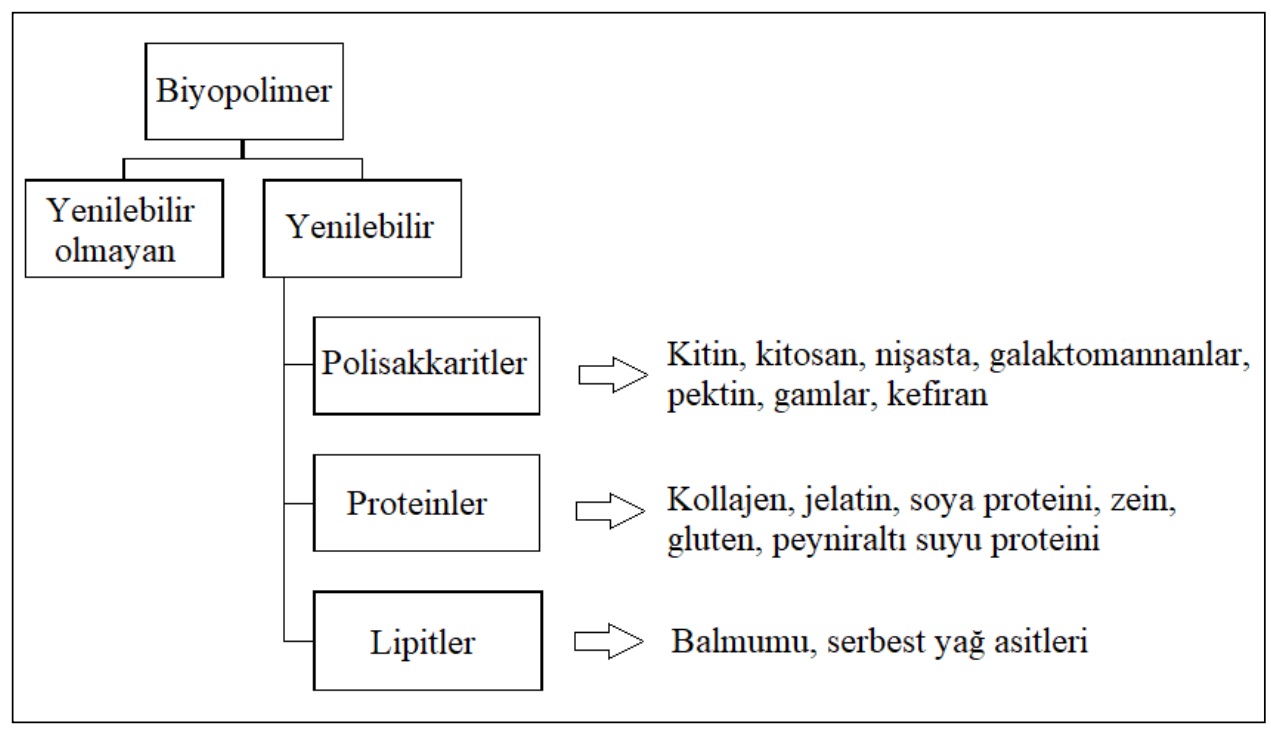

Şekil 1. Biyobozunur film üretiminde kullanılan biyopolimerler (Nur Hanani ve ark. 2014).

Yenilebilir filmlerin gıda ile interaksiyonu sonucunda gıdanın istenilen bir özelliğinin geliştirilmesi, filmin fiziksel ve mekanik özelliklerinin iyileştirilmesi ile gıda kalite ve güvenliğinin artırılması gibi amaçlarla filme çeşitli fonksiyonel katkı maddeleri ilave edilmektedir. Bu maddeler emülsifiye edici ajanlar, nutrasötikler, renk ve lezzet maddeleri, antioksidanlar, antimikrobiyeller ya da canlı mikroorganizmalar olabilir (Han 2014).

\section{Yenilebilir Film ve Kaplamaların Uygulama Yöntemleri}

Yenilebilir film ve kaplama uygulamalarında genellikle beş yöntem kullanılmaktadır: daldırma, püskürtme, fırçalama, film dökme ve ekstrüzyon (Aruna ve ark. 2012). Bu işlemleri genellikle su fazlı ürünler için kurutma, lipit bazlı ürünler için ise soğutma işlemi takip etmektedir (Gontard ve Guilbert 1994). Film dökme ve ekstrüzyon yöntemleri yenilebilir film üretiminde kullanılmakta iken, ürün yüzeyinin direkt olarak kaplanmasında diğer yöntemlere başvurulmaktadır. 
Genellikle meyve ve sebzelerin kaplanmasında yaygın olarak kullanılan daldırma uygulanması kolay olan bir yöntemdir (Vargas ve ark. 2008). Bu yöntemde, ürün direk olarak kaplama solüsyonuna daldırılmakta, sonrasında solüsyondan uzaklaştırılarak kurutmaya bırakılmaktadır. Daldırma süresi genellikle 5-30 saniye arasında değişmektedir (Ayrancı ve Tunç 1997; Vargas ve ark. 2006). Bu yöntemin uygulanması sırasında yoğunluk, viskozite ve yüzey gerilimi gibi solüsyona ait olan çeşitli faktörlerin yanı sıra kaplanacak ürün ile solüsyonun uygulanma süresinin dikkate alınması gerekmektedir (Snoeijer ve ark. 2008).

Püskürtme yöntemi, kaplama solüsyonunun çok viskoz olmadığı durumlarda kullanılan bir yüzey kaplama uygulamasıdır. Yüksek viskozitede bir solüsyon kullanılması halinde püskürtme işlemi kolaylıkla yapılamamakta ve elde edilen kaplama kalın olmaktadır (Skurtys ve ark. 2014). Klasik püskürtme sistemlerinde yaklaşı 20 mikrona kadar olan boyutlarda damlacıklar elde edilirken elektropüskürtme yöntemi ile polimer ya da polimer karışımlarından 100 nm'nin altında partiküller elde edilebilmektedir (Pareta ve Edirisinghe 2006).

Boyama (firçalama) metodu; akışkan haldeki kaplama solüsyonunun ürün üzerine bir firça yardımıyla kaplanması ve kaplanan yüzeyin kurutulması ile gerçekleştirilmektedir (Polat 2007). Ürünün belli bir bölgesi ya da tamamı kaplanabilmektedir (Tural ve ark. 2017).

Dökme yöntemi; düzgün bir ürün yüzeyine film oluşturacak çözeltinin belirlenen kalınlıkta dökülüp, yayılması ve kurutulması ile film oluşturulmasıdır.

Filmin yapısı; çözelti bileşimi, film döküm kalınlığı ve kurutma koşullarına bağlı olarak değişmektedir. Bu yöntemle oluşturulan filmlerin direkt uygulamaları sınırlı olup, çoğunlukla püskürtme ve daldırma yöntemleri ile birlikte kullanilmaktadır (Krochta ve ark. 1997).

\section{Mikroorganizma Taşıyıcısı Olarak Yenilebilir Film Ve Kaplamalar}

Günümüze kadar geliştirilen aktif ambalajlama uygulamaları; ürünlerde oluşabilecek problemleri engellemek amacıyla oksijen tutucuların, etilen tutucuların, karbondioksit düzenleyicilerin, antioksidanların, fenolik bileşiklerin ve antimikrobiyel özellikteki maddelerin ambalaj materyallerinin bileşimine dâhil edilmesi üzerine yoğunlaşmıştır (Coma ve ark. 2002). Son yıllarda hem çevresel endişeler hem de tüketici tercihlerindeki yönelimlerin etkisi ile aktif ambalajlamada da yeni teknik ve yöntemlerin geliştirilmesine yönelik araştırmalar yapılmaktadır. Yenilebilir özellikteki film ve kaplama materyali içerisine canlı mikroorganizmaların ilavesi, yeni sayılabilecek tekniklerden bir tanesidir. Bu amaçla yapılan çalışmalar, filmlerin probiyotik mikroorganizmalar ve mayaların taşıyıcısı olarak kullanımı üzerine yoğunlaşmıştır. Canlı mikroorganizmaların yenilebilir film ve kaplamalarda kullanılması üzerine bazı ilave kriterler söz konusudur: i) probiyotik ya da antimikrobiyel etkilerini gösterebilmeleri için canlılıklarını uygulama/depolama sürecinde korumalı ve belli bir hücre sayısında olmalıdırlar, ii) film/kaplamanın mekanik ve bariyer özelliklerini değiştirmemelidirler ve iii) uygulandığı gıdanın duyusal özelliklerini olumsuz yönde etkilememelidirler (Guimarães ve ark. 2018).

\section{Probiyotik bakteri taşıyıcısı olarak yenilebilir film ve kaplamalar}

Probiyotik terimi, FAO/WHO (2002) tarafından "Yeterli miktarda alındıklarında konakçı canlının sağlığında olumlu bir etki sağlayan canlı mikroorganizma" şeklinde tanımlanmıştır. Probiyotik mikroorganizmaların çoğu Lactobacillus ve Bifidobacterium cinslerine dâhil olmakla birlikte Bacillus, Clostridium, Escherichia, Enterobacter ve Pediococcus gibi diğer cinsler içerisinde de sınırlı sayıda probiyotik suş yer almaktadır. (Prado ve ark. 2008). Bir suşun probiyotik olarak nitelendirilebilmesi için insan sağlığına faydalı olması, aside ve safra tuzuna dirençli olması, insan epitel hücrelerine tutunabilmesi, bağırsaklarda kolonize olabilmesi, bakteriyosin denilen antimikrobiyal maddeleri üretebilmesi gibi bazı şartları taşıması gerekmektedir (Jack ve ark. 1995). Ayrıca, GRAS statüsünde yer alma, düşük maliyetli olma, gıdaların işlenmesi ve depolanması sırasında canlı kalabilme, ürünlere uygulanabilme ve fizikokimyasal proseslere karşı dirençlilik gibi özelliklere de sahip olmalıdırlar (Prado ve ark. 2008).

Tüketici bilincinin artmasıyla birlikte fonksiyonel gıdalara olan ilgi giderek artmaktadır. Dünya piyasasında 2000 yılında fonksiyonel gıda ve içeceklere 33 milyar dolar harcanmış olup, 2013 yılında bu rakam 176,7 milyar dolara ulaşmıştır. Bu rakam, gıda marketlerine harcanan payın \%5'ine karşılık gelmektedir (Granato ve ark. 2010). Fonksiyonel gıda marketlerinin \%60-70’lik kısmını probiyotik gıdalar oluşturmaktadır (Kołozyn-Krajewskaa ve Dolatowski 2012). İnsanların sağlıklı yaşama konusunda bilincinin artması ile birlikte probiyotik taşıyıcısı ürünlere olan ilgi de gittikçe daha da artmaktadır. Buna bağlı olarak, gelecek 5 yıl içerisinde probiyotiklerin ekonomik büyüklüğünün 57 milyar ABD dolarını aşacağı tahmin edilmektedir (Brodwin 2017).

Ticari olarak mevcut probiyotik taşıyıcısı fermente gıdaların önemli bir bölümünü yoğurt ve kefir gibi süt bazlı ürünler oluşturmaktadır. Bununla birlikte, vejetaryenlik, laktoz intoleransı, süt proteini alerjisi, sütteki kolesterol içeriği gibi çeşitli faktörlerden dolayı tüketici talepleri süt bazlı olmayan probiyotik taşıyıcısı ürünlere yönelmiştir (Ray ve Sivakumar 2009). 
Probiyotik bakterilerin yenilebilir kaplamalara ilave edilmesi probiyotik ürünlerin geliştirilmesinde yenilikçi bir yöntem olup ürünlere farklı lezzetler kazandırılmakta, gıdaların kalitesi artırılmakta ve raf ömrü uzatılmaktadır.

Çizelge 1'de görüldüğü üzere, farklı cinslere ait probiyotik bakteriler ile birlikte farklı polimer matriks ve katkı maddeleri kullanılarak probiyotik taşıyıcısı yenilebilir filmler elde edilmiştir. Bu filmlerde mikroorganizmaların canlılığı incelenmiş ve bu filmlerin karakterizasyonları gerçekleştirilmiştir. Sánchez-González ve ark. (2014), $L b$. acidophilus ve $L b$. reuteri içeren sodyum kazeinat ve metilselüloz bazlı filmlerin antilisterial aktivitesini araştırmışlardır (Çizelge 1). Araştırma sonucunda, bakteri ilavesinin filmlerin fiziksel özelliklerinde önemli değişikliklere yol açmadığı görülürken, Listeria innocua’yı bir hafta süre ile inhibe ettikleri gözlemlenmiştir. Üretilen sodyum kazeinat filmlerde laktik asit bakterilerin canlılığı daha yüksek olmuştur.

Lb. rhamnosus GG ilave edilerek peyniraltı suyu konsantresi ve sodyum aljinat bazlı yenilebilir filmler oluşturulmuş ve bu filmlerle kaplanan ekmeklerin raf ömrü incelenmiştir. Lb. rhamnosus GG ilave edilen yenilebilir filmlerle kaplanan ekmeklerde nişasta retrogradasyonunun önlendiği, bayatlamanın geciktiği ve ekmek örneklerinin raf ömrünün uzadığı tespit edilmiştir (Soukoulis ve ark. 2014).

Romano ve ark. (2014), Lb. delbrueckii subsp. bulgaricus CIDCA 333 ve $L$ b. plantarum CIDCA 83114 taşıyıcısı metilselüloz yenilebilir film üretmişlerdir. Araştırma sonucunda bakteri ilavesinin, film homojenliğinde olumsuzluğa neden olmazken fruktooligosakkarit ilavesinin filmde plastikleştirici etki gösterdiğini ve Lb. plantarum‘un \%33 ve \%44 nispi nemde 45 gün boyunca canlılığını devam ettirdiğini tespit etmişlerdir.

B. animalis ve $L b$. casei içeren peyniraltı suyu proteini bazlı filmlerde 4 ve $23{ }^{\circ} \mathrm{C}$ 'de depolama sırasında 60 güne kadar bakteri canlılığında 3 log'a kadar azalmalar meydana gelirken, B. animalis'in canlılığını daha iyi koruduğu saptanmıştır (Çizelge 1). Filmlerin renk, su aktivitesi, kalınlık gibi fiziksel özellikleri ile moleküler yapı ve mekanik özellikleri depolama sırasında değişmemiştir (Odila Pereira ve ark. 2016).

Ebrahimi ve ark. (2018) Lb. acidophilus, Lb. casei, Lb. rhamnosus ve B. bifidum içeren karboksimetilselüloz bazlı filmlerin 42 günlük depolama sırasında fiziksel özelliklerini incelemiş̧lerdir. $4{ }^{\circ} \mathrm{C}$ 'de depolanan filmlerde $L b$. acidophilus ve $L b$. rhamnosus sayıs $10^{7} \mathrm{kob} / \mathrm{g}$ düzeyinde kalmıştır. Bakteri ilavesi filmlerin su buharı geçirgenliği ve opaklığını artırırken, çekme mukavemeti ve kopma dayanımı gibi mekanik özelliklerini azaltmıştır.

Yapılan başka bir çalışmada, kaplama materyali olarak Lb. rhamnosus GG içeren düşük ve yüksek yoğunluklu sodyum aljinat, düşük esterifikasyon derecesine sahip pektin, kapa-karajenan/keçiboynuzu gamı ve jelatin bazlı (peyniraltı suyu konsantresi katkılı ya da katkısız) ince yenilebilir filmler üretilmiştir. Kapa-karajenan/keçiboynuzu gamı bazlı filmler, test edilen depolama sıcaklıklarında $\left(4\right.$ ve $\left.25^{\circ} \mathrm{C}\right)$ en yüksek bakteri canlılığını sağlamıştır. Peyniraltı suyu konsantresi ilavesi, filmlerin raf ömründe 1,8-6,5 kat artış meydana getirmiştir. Peynir altı suyu konsantresi ilaveli yüksek yoğunluklu sodyum aljinat ve kapa-karajenan/keçiboynuzu gamı filmler ise en uygun mekanik ve bariyer özellikleri göstermiştir (Soukoulis ve ark. 2017).

Probiyotik taşıyıcısı yenilebilir film ve kaplamaların gıdalarda kullanımı üzerine yapılmış çalışmalar Çizelge 2'de özetlenmiştir. Çizelgede görüldüğü üzere, farklı cinslere ait probiyotik bakteriler ile zenginleştirilmiş yenilebilir filmler, taze/minimal işlenmiş meyve-sebzeler, balık, fırın ürünleri ve peynir gibi farklı kaynaklardan üretilmiş ve çok farklı özelliklere sahip gıda maddelerinin kaplanmasında uygulanmış ve başarılı sonuçlar elde edilmiştir.

Balıkla ilgili yapılan bir çalışmada; polimer matriks olarak sodyum aljinat ve nişasta ile Carnobacterium maltaromaticum içeren yenilebilir filmin soğuk tütsülenmiş somon balığında L. monocytogenes gelişimini inhibe ettiği gözlemlenmiştir (Concha-Meyer ve ark. 2011).

İşlenmiş balıkların raf ömrünü uzatmak ve onlara probiyotik taşıyıcısı özellik kazandırabilmek amacıyla balıklar $L b$. acidophilus ve B. bifidum içeren jelatin bazlı filmler ile kaplanmıştır. Çalışma sonucunda, probiyotik mikroorganizmaların depolama süresince stabilitesini koruduğu ve probiyotik katkılı jelatin bazlı yenilebilir filmlerin yüksek basınç gibi diğer teknolojiler ile birlikte uygulanmasının özellikle balıkların raf ömrünün uzatılmasında etkili olduğu tespit edilmiştir (López de Lacey ve ark. 2012).

Meyveler üzerine yapılan bir araştırmada ise papaya ve elma porsiyonlarının B. lactis BB-12 ilave edilen aljinat ve jellan bazlı yenilebilir filmle kaplanmıştır. Çalışma sonucunda, meyvelerde Bifidobakterilerin $2{ }^{\circ} \mathrm{C}$ 'de 10 gün canlılığını koruduğu belirlenmiştir (Tapia ve ark. 2007).

Ekmeğin fonksiyonel özelliğinin geliştirilmesinin istendiği bir araştırmada; Lb. acidophilus içeren nişasta polimerine katkı maddesi olarak peynir altı suyu proteini mikrokapsülleri, karboksimetilselüloz, pektin, inülin ve agave ilave 
edilerek filmler üretilmiş ve ekmeğin depolanması süresince probiyotik bakterinin canlılığını koruduğu bildirilmiştir (Altamirano-Fortoul ve ark. 2012).

Gialamas ve ark. (2010); probiyotik bir tür olan $L b$. sakei içeren sodyum kazeinat filmi L. monocytogenes ile kontamine edilen gıdalar için kaplama materyali olarak kullanılmışlardır. Lb. sakei'nin antimikrobiyel etkisi ile taze ette depolama süresince $L$. monocytogenes' in sayısını önemli ölçüde azalttığı gözlenmiştir.

\section{Maya içeren yenilebilir film ve kaplamalar}

Mayalar; ökaryot hücre yapısına sahip olan, funguslar içerisinde yer alan tek hücreli mikroorganizmalardır. Gıda endüstrisinde özellikle fermentasyon uygulamalarında yaygın olarak kullanılmaktadır. Bunların yanı sıra modern gıda biyoteknolojisinde tek hücre proteini ve çeşitli ticari enzimlerin üretiminde mayalardan faydalanılmaktadır. Son yıllarda ise çalışmalar meyve ve sebzelerin hasat sonrası muhafazasında biyokontrol amacıyla mayaların kullanımları üzerine yoğunlaşmıştır (Liu ve ark. 2013). Mayaların yenilebilir film formülasyonlarında kullanımı probiyotik bakteriler kadar yaygın olmamakla birlikte yapılmış olan çalışmalar Çizelge 3'te özetlenmiştir.

Çizelge 3’de özetlenen çalışmalara göre mayalar, özellikle de öldürücü maya olarak nitelendirilen türler, meyve ve sebzelerde, nadiren de süt ürünlerinde yenilebilir film ve kaplama formülasyonlarına dâhil edilerek bu gıdalarda biyokontrol amacıyla kullanılmıştır. Meyve ve sebzelerde özellikle küflenmeden kaynaklanan çürüme ve raf ömrü kaybının maya içeren yenilebilir film formülasyonlarıyla azaltılabildiği ve ürünlerin hasat sonrası raf ömürlerinin uzatılabildiği vurgulanmıştır. 
Çizelge 1. Probiyotik taşıyıcısı yenilebilir film ve kaplamalar üzerine yapılmış çalışmalar.

\begin{tabular}{|c|c|c|c|c|}
\hline $\begin{array}{c}\text { Probiyotik } \\
\text { mikroorganizma }\end{array}$ & Polimer matriksi & Katkı maddeleri & Sonuç & Kaynak \\
\hline $\begin{array}{l}\text { Lactobacillus rhamnosus } \\
\text { GG }\end{array}$ & $\begin{array}{l}\text { Düşük ve yüksek yoğunluklu } \\
\text { sodyum aljinat, pektin, kapa- } \\
\text { karajenan/keçiboynuzu gamı, } \\
\text { jelatin }\end{array}$ & $\begin{array}{l}\text { Peyniraltı suyu } \\
\text { konsantresi }\end{array}$ & $\begin{array}{c}\text { Kapa-karajenan /keçiboynuzu gamı bazlı } \\
\text { filmlerde en yüksek canlılık. Peyniraltı suyu } \\
\text { konsantresi ilavesi ile filmlerin raf ömründe 1,8- } \\
6,5 \text { kat artış }\end{array}$ & Soukoulis ve ark.( 2017) \\
\hline $\begin{array}{l}\text { Bifidobacterium animalis ve } \\
\text { Lb. casei }\end{array}$ & Peyniraltı suyu proteini & - & $\begin{array}{l}\text { B. animalis daha uzun süre canlı kalmıştır. } \\
\text { Bakteri ilavesi, filmlerin özelliklerini } \\
\text { değiştirmemiştir. }\end{array}$ & $\begin{array}{l}\text { Odila Pereira ve ark. } \\
\qquad \text { (2016) }\end{array}$ \\
\hline $\begin{array}{l}\text { Lb. acidophilus ve } L b . \\
\text { reuteri }\end{array}$ & $\begin{array}{l}\text { Sodyum kazeinat, } \\
\text { metilselüloz }\end{array}$ & - & $\begin{array}{c}\text { Listeria innocua'ya karşı } 1 \text { hafta boyunca tam } \\
\text { inhibisyon }\end{array}$ & $\begin{array}{l}\text { Sánchez-González ve ark. } \\
\text { (2014) }\end{array}$ \\
\hline $\begin{array}{c}\text { Lb. delbrueckii } \\
\text { subsp. bulgaricus, } L b \text {. } \\
\text { plantarum CIDCA } 83114\end{array}$ & Metilselüloz & Fruktooligosakkarit & $\begin{array}{l}\text { Lb. plantarum, \% } 33 \text { ve \% } 44 \text { nispi nemde } 45 \\
\text { gün boyunca canlılığını devam ettirmiştir. }\end{array}$ & Romano ve ark. (2014) \\
\hline $\begin{array}{l}\text { Lb. acidophilus, Lb. casei, } \\
\text { Lb. rhamnosus, B. bifidum }\end{array}$ & Karboksimetilselüloz & - & $\begin{array}{c}4{ }^{\circ} \mathrm{C} \text { 'de depolanan filmlerde } L b \text {. acidophilus ve } \\
L b \text {. rhamnosus sayısı } 10^{7} \mathrm{kob} / \mathrm{g} \text { düzeyinde } \\
\text { kalmıştır. }\end{array}$ & Ebrahimi ve ark. (2018) \\
\hline $\begin{array}{l}\text { Lb. plantarum, } \\
\text { Kluyveromyces marxianus }\end{array}$ & Kefiran & Gliserol & $\begin{array}{l}\text { Depolama süresince canlılık devam etti. } 20 \text { C'de } \\
35 \text { günde } L b \text {. plantarum'da } 1.3 \text { log, } K . \\
\text { marxianus'ta } 0.7 \text { log azalma oldu. }\end{array}$ & Piermaria ve ark. (2015) \\
\hline Lb. rhamnosus GG & Jelatin & $\begin{array}{l}\text { İnülin, polidekstroz, } \\
\text { gluko- } \\
\text { oligosakkaritler, } \\
\text { buğday dekstrini }\end{array}$ & $\begin{array}{c}\text { Gluko-oligosakkarit ve polidekstroz ilavesi } \\
\text { kurutma sırasında bakteri canlılığını artırdı. } \\
\text { İnülin depolama sırasında bakteride koruyucu } \\
\text { etki yaptı. }\end{array}$ & Soukoulis ve ark. (2014a) \\
\hline Lb. rhamnosus GG & $\begin{array}{l}\text { Mısır ve pirinç nişastası, } \\
\text { jelatin, sodyum kazeinat, } \\
\text { soya proteini konsantresi }\end{array}$ & Gliserol & $\begin{array}{l}\text { Protein varlığında kuruma sırasında daha düşük } \\
\text { hücre kaybı. Depolama sırasında bakteri canlılığı } \\
\text { üzerinde protein-nişasta arasında sinerjist etki }\end{array}$ & Soukoulis ve ark. (2016) \\
\hline $\begin{array}{l}L . \text { plantarum GG, } L b \text {. } \\
\text { reuteri, Lb. acidophilus }\end{array}$ & $\begin{array}{l}\text { Pullulan, patates, misır ve } \\
\text { tapyoka nişastası }\end{array}$ & - & $\begin{array}{l}\text { Pullulan ve pullulan/patates nişastası bazlı filmler } \\
\text { depolama sırasında bakteri taşımak için en uygun } \\
\text { matris olarak bulundu. }\end{array}$ & Kanmani ve ark. (2013) \\
\hline B. longum & Arabinoksilan & Lakkaz & $\begin{array}{c}\text { Bakteri varlığı, petek şeklinde mikro yapılar } \\
\text { meydana getirdi. }\end{array}$ & $\begin{array}{l}\text { Morales-Ortega ve ark. } \\
\text { (2014) }\end{array}$ \\
\hline
\end{tabular}


Çizelge 2. Probiyotik tașıyıcısı yenilebilir film ve kaplamaların gıdalarda kullanımı üzerine yapılmıș çalıșmalar

\begin{tabular}{|c|c|c|c|c|c|}
\hline $\begin{array}{c}\text { Probiyotik } \\
\text { mikroorganizma }\end{array}$ & Polimer matriksi & Katkı maddeleri & Uygulanan gida & Sonuç & Kaynak \\
\hline B. lactis $\mathrm{Bb}-12$ & Aljinat ve jellan & $\begin{array}{c}\text { Gliserol, } \mathrm{N} \text {-asetilsistein, } \\
\text { askorbik asit, ayçiçeği yağı, } \\
\mathrm{CaCl}_{2}\end{array}$ & $\begin{array}{c}\text { Taze kesilmiş elma } \\
\text { ve papaya }\end{array}$ & Nem kaybında azalma & Tapia ve ark. (2007) \\
\hline Lb. acidophilus & Sodyum aljinat & $\mathrm{CaCl}_{2}$, sodyum sitrat & Çilek & Nem kaybında azalma & Moayednia ve ark. (2009) \\
\hline Lb. sakei & Sodyum kazeinat & Sorbitol & Taze et & $\begin{array}{l}\text { Listeria monocytogenes } \\
\text { inhibisyonu }\end{array}$ & Gialamas ve ark. (2010) \\
\hline $\begin{array}{l}\text { Carnobacterium } \\
\text { maltaromaticum }\end{array}$ & Aljinat ve nişasta & Nisin, gliserol & $\begin{array}{l}\text { Soğuk tütsülenmiş } \\
\text { somon }\end{array}$ & $\begin{array}{l}\text { Listeria monocytogenes } \\
\text { inhibisyonu }\end{array}$ & Concha-Meyer ve ark. (2011) \\
\hline Lb. acidophilus & Nişasta & $\begin{array}{l}\text { Peynir altı suyu proteini } \\
\text { mikrokapsülleri, } \\
\text { Karboksimetilselüloz, pektin, } \\
\text { inülin, agave }\end{array}$ & Ekmek & $\begin{array}{c}\text { Probiyotik fonksiyonel ekmek } \\
\text { üretimi }\end{array}$ & $\begin{array}{l}\text { Altamirano-Fortoul ve ark. } \\
\text { (2012) }\end{array}$ \\
\hline $\begin{array}{l}\text { Lb. acidophilus ve } B \text {. } \\
\text { bifidum }\end{array}$ & Jelatin & $\begin{array}{l}\text { Glikoz ve sistein. Sorbitol ve } \\
\text { gliserol plastikleştirici olarak }\end{array}$ & Hake balığ1 & $\begin{array}{c}\mathrm{H}_{2} \mathrm{~S} \text { üreten mikroorganizmaların } \\
\text { inhibisyonu }\end{array}$ & López de Lacey ve ark. (2012) \\
\hline Lb. rhamnosus GG & $\begin{array}{l}\text { Sodyum aljinat ve } \\
\text { peynir altı suyu } \\
\text { proteini }\end{array}$ & Gliserol & Ekmek & $\begin{array}{l}\text { Probiyotik firın ürünü üretimi, } \\
\text { bayatlamada gecikme }\end{array}$ & Soukoulis ve ark. (2014b) \\
\hline Lb. acidophilus & Sodyum aljinat & $\begin{array}{l}\text { Gliserol, Ayçiçek yağı, tween } \\
\text { 80, } \mathrm{CaCl}_{2}\end{array}$ & Havuç & $\begin{array}{l}\text { Renk ve nem kaybının } \\
\text { önlenmesi }\end{array}$ & Shigematsu ve ark. (2018) \\
\hline $\begin{array}{l}\text { Serbest ve enkapsüle } \\
\text { Lb. acidophilus }\end{array}$ & Nişasta & - & $\begin{array}{c}\text { Manaba taze beyaz } \\
\text { peyniri }\end{array}$ & $\begin{array}{l}\text { Mikrobiyolojik kalitede } \\
\text { iyileşme }\end{array}$ & Santacruz ve ark. (2018) \\
\hline Lb. plantarum & Metilselüloz & Sitrik asit, sorbitol & $\begin{array}{c}\text { Atıştırmalık } \\
\text { fırınlanmış yeşil } \\
\text { elma }\end{array}$ & $\begin{array}{l}90 \text { günlük depolama boyunca } \\
\text { yüksek bakteri canlılığ } 1\end{array}$ & Tavera-Quiroz ve ark. (2015) \\
\hline $\begin{array}{l}\text { Bacillus subtilis } \\
\text { HFC103 }\end{array}$ & $\begin{array}{l}\text { Guar gam, } \\
\text { Kandelilla } \\
\text { balmumu }\end{array}$ & Gliserol, gallik asit & Çilek & $\begin{array}{c}\text { Çürüme 6. Güne kadar \%100 } \\
\text { geciktirildi, Rhizopus stolonifer } \\
\text { kontrol altına alındı. }\end{array}$ & Oregel-Zamudio ve ark. (2017) \\
\hline
\end{tabular}


Çizelge 3. Maya içeren yenilebilir filmler üzerine yapılmıș çalıșmalar

\begin{tabular}{|c|c|c|c|c|c|}
\hline Maya & Polimer matriksi & Katkı maddeleri & $\begin{array}{c}\text { Uygulanan } \\
\text { gida }\end{array}$ & Sonuç & Kaynak \\
\hline $\begin{array}{l}\text { Wickerhamomyces anomalus, } \\
\text { Metschnikowia pulcherrima, } \\
\text { Aureobasidium pullulan }\end{array}$ & Keçiboynuzu gamı & - & Mandalina & $\begin{array}{c}\text { Meyvede Penicillium } \\
\text { digitatum ve } P . \text { italicum } \\
\text { inhibisyonu }\end{array}$ & Parafati ve ark. (2016) \\
\hline Candida oleophila & $\begin{array}{l}\text { Metil selüloz, } \\
\text { hidroksipropil selüloz, } \\
\text { şellak }\end{array}$ & - & Greyfurt & $\begin{array}{c}\text { Depolama süresi 9-11 gün } \\
\text { uzadı. }\end{array}$ & $\begin{array}{l}\text { McGuire ve ark. } \\
\text { (1994) }\end{array}$ \\
\hline Cryptococcus laurentii & Kitosan & Tween 80 & Üzüm & $\begin{array}{l}\text { Hasat sonrası bozulma } \\
\text { geciktirildi. }\end{array}$ & Meng ve ark. (2010) \\
\hline Cryptococcus laurentii & Sodyum aljinat & $\begin{array}{l}\text { Gliserol, palmitik } \\
\text { asit, } \beta \text {-siklodekstrin, } \\
\text { gliserol monostearat }\end{array}$ & Çilek & $\begin{array}{l}\text { Çilek renginde bozulma } \\
\text { olmadan küflenme } \\
\text { geciktirildi. }\end{array}$ & Fan ve ark. (2009) \\
\hline Williopsis saturnus var. saturnus & $\begin{array}{c}\text { Peyniraltı suyu proteini } \\
\text { konsantresi }\end{array}$ & - & Kaşar peyniri & $\begin{array}{l}\text { Fungal gelişim depolama } \\
\text { süresince inhibe edildi. }\end{array}$ & Civelek ve ark. (2017) \\
\hline $\begin{array}{c}\text { Candida guilliermondii ve } \\
\text { Debaryomyces sp. }\end{array}$ & $\begin{array}{l}\text { Karboksimetil selüloz, } \\
\text { hidroksipropil selüloz, } \\
\text { metil selüloz }\end{array}$ & Glukoz, $\mathrm{CaCl}_{2}$ & Portakal & Çürüme geciktirildi. & $\begin{array}{l}\text { Potjewijd ve ark. } \\
\text { (1995) }\end{array}$ \\
\hline C. oleophila & Şellak & $\begin{array}{l}\text { Etanol, morfolin, } \\
\text { KOH, amonyak, oleik } \\
\text { asit, propilen glikol }\end{array}$ & Greyfurt & $\begin{array}{l}\text { Hasat sonrası depolama } \\
\text { süresi 9-14 gün uzatıldı. }\end{array}$ & $\begin{array}{c}\text { McGuire ve } \\
\text { Hagenmaier (1996) }\end{array}$ \\
\hline C. oleophila & Şellak, sükroz esteri & $\begin{array}{l}\text { Propilen glikol, oleik } \\
\text { asit, polisorbat } 80\end{array}$ & Greyfurt & $\begin{array}{c}\text { Hasat sonrası çürüme } \\
\text { geciktirildi. }\end{array}$ & $\begin{array}{c}\text { McGuire ve } \\
\text { Dimitroglou (1999) }\end{array}$ \\
\hline C. utilis & Kitosan & Tween 80 & Domates & $\begin{array}{c}\text { Alternaria alternata } \\
\text { and Geotrichum candidum } \\
\text { kaynaklı çürüme } \\
\text { geciktirildi. }\end{array}$ & Sharma ve ark. (2006) \\
\hline
\end{tabular}


Çizelge 3 (devam). Maya içeren yenilebilir fillmler üzerine yapılmış çalışmalar

\begin{tabular}{|c|c|c|c|c|c|}
\hline Maya & Polimer matriksi & $\begin{array}{c}\text { Katkı } \\
\text { maddeleri }\end{array}$ & $\begin{array}{c}\text { Uygulanan } \\
\text { gida }\end{array}$ & Sonuç & Kaynak \\
\hline Bira mayası & $\begin{array}{l}\text { Karboksimetil } \\
\text { selüloz, aljinat }\end{array}$ & - & Üzüm & $\begin{array}{c}\text { Nem kaybında azalma, C } \\
\text { vitaminin korunması, } \\
\text { koruyucu enzimlerin } \\
\text { aktivitesinin artması }\end{array}$ & Yinzhe ve Shaoying (2013) \\
\hline C. sake CPA-1 & $\begin{array}{l}\text { Hidroksipropilmetil } \\
\text { selüloz, nişasta, } \\
\text { sodyum kazeinat, } \\
\text { bezelye proteini }\end{array}$ & $\begin{array}{l}\text { Gliserol, oleik } \\
\text { asit, Span 80, } \\
\text { Tween } 85\end{array}$ & Üzüm & $\begin{array}{l}\text { Botrytis cinerea’ya karş1 } \\
\text { koruyucu etki }\end{array}$ & Marín ve ark. (2016) \\
\hline $\begin{array}{l}\text { Wickerhamomyces } \\
\text { anomalus }\end{array}$ & $\begin{array}{l}\text { Sodyum aljinat, } \\
\text { keçiboynuzu gamı }\end{array}$ & Gliserol & Portakal & $\begin{array}{c}\text { Portakalda Penicillium } \\
\text { digitatum kontrolünün } \\
\text { sağlanması }\end{array}$ & Aloui ve ark. (2015) \\
\hline Debaryomyces hansenii & Arabinoksilan & Lakkaz, gliserol & $\begin{array}{c}\text { İran } \\
\text { limonu }\end{array}$ & $\begin{array}{c}\text { Mavi küf çürümesinin } \\
\text { önlenmesi }\end{array}$ & González-Estrada ve ark. (2017) \\
\hline C. sake CPA-1 & $\begin{array}{l}\text { Hidroksipropilmetil } \\
\text { selüloz, nişasta, } \\
\text { sodyum kazeinat, } \\
\text { bezelye proteini }\end{array}$ & $\begin{array}{l}\text { Oleik asit, Span } \\
\text { 80, Tween } 85\end{array}$ & - & $\begin{array}{c}\text { Protein filmlerde kurutma } \\
\text { sirasında daha yüksek hücre } \\
\text { canlılığı }\end{array}$ & Marín ve ark. (2017) \\
\hline $\begin{array}{l}\text { Williopsis saturnus var. } \\
\text { saturnus }\end{array}$ & $\begin{array}{l}\text { Peyniraltı suyu } \\
\text { proteini konsantresi }\end{array}$ & Gliserol & - & $\begin{array}{l}\text { P. expansum ve Aspergillus } \\
\text { niger inhibisyonu }\end{array}$ & Karabulut ve ark. (2018) \\
\hline D. hansenii & Arabinoksilan & Lakkaz, gliserol & - & $\begin{array}{l}\text { Maya içeren filmlerde } \\
\text { granül benzeri ve lifli } \\
\text { mikroyapılar oluştu, çekme } \\
\text { dayanımı, kopma anında } \\
\text { uzama ve Young modülü } \\
\text { düştü. }\end{array}$ & González-Estrada ve ark. (2015) \\
\hline
\end{tabular}




\section{Sonuç}

Gelişen teknolojiyle birlikte gıda üretiminde enzimatik ve bakteriyel bozulmanın geciktirilmesi amacıyla farklı muhafaza yöntemleri ve ambalajlama teknikleri kullanılmaktadır. Yenilebilir film ve kaplamalar; gıdaların kalite özelliklerini korumak ve raf ömürlerini uzatmak amacıyla son dönemlerde gıda endüstrisinin çeşitli alanlarında yaygın olarak kullanılmaktadır. Yapılan çalışmalar, yenilebilir film ve kaplamaların mikroorganizmalar için etkin ve uygun taşıyıcı olduklarını ortaya koymaktadır. Yenilebilir özellikteki biyopolimerler, içerisine ilave edilen mikroorganizma için koruyucu özellik göstermekte ve olumsuz çevresel faktörlere karşı onun canlılı̆̆ını muhafaza etmesine yardımcı olmaktadır. Yenilebilir film ve kaplama uygulamalarında taşınan mikroorganizmalar genellikle probiyotik bakteriler ve antagonist mayalar arasından seçilmektedir. Bu mikroorganizmaların seçiminde, gıdaya fonksiyonel bir özellik kazandırmanın yanı sıra gıdanın raf ömrünün uzatılması ve dayanıklılığının artıılmasındaki etkisi rol oynamaktadır. $\mathrm{Bu}$ mikroorganizmaların antimikrobiyel özellikleri patojen ve bozucu mikroorganizmaların kontrolünde etkili olmaktadır. Sonuç olarak, mikroorganizma taşıyıcısı yenilebilir film ve kaplamaların gıda endüstrisi açısından umut vadeden bir uygulama olduğu, fonksiyonel gıda üretiminin yanı sıra gıdaların raf ömürlerinin uzatılmasında alternatif bir yöntem olarak kullanılabileceği ve gelecekte bu tekniğin daha da yaygınlaşacağı düşünülmektedir.

\section{Kaynaklar}

Abdul Khalil HPS, Davoudpour Y, Saurabh CK, Hossain MS, Adnan AS, Dungani R, Paridah MT, Islam Sarker MZ, Fazita MRN, Syakir MI, Haafiz MKM (2016). A review on nanocellulosic fibres as new material for sustainable packaging: Process and applications. Renewable and Sustainable Energy Reviews 64: 823-836.

Aloui H, Licciardello F, Khwaldia K, Hamdi M, Restuccia C (2015). Physical properties and antifungal activity of bioactive films containing Wickerhamomyces anomalus killer yeast and their application for preservation of oranges and control of postharvest green mold caused by Penicillium digitatum. International Journal of Food Microbiology 200: 22-30.

Altamirano-Fortoul R, Moreno-Terrazas R, Quezada-Gallo A, Rosell CM (2012). Viability of some probiotic coatings in bread and its effect on the crust mechanical properties. Food Hydrocolloids 29 (1): 166-174.

Aruna D, Sasikala P, Lavanya R, Kavitha V, Yazhini G, Banu MS (2012). Edible films from polysaccharides. Food Science and Quality Management 3: 9-18.

Avella M, De Vlieger JJ, Errico ME, Fischer S, Vacca P, Volpe MG (2005). Biodegradable starch/clay nanocomposite films for food packaging applications. Food Chemistry 93 (3): 467-474.

Ayrancı E, Tunç S (1997). Cellulose-based edible films and their effects on fresh beans and strawberries. Zeitschrift für Lebensmitteluntersuchung und-forschung A 205 (6): 470-473.

Brodwin E (2017). Why a pill with barely any health benefits could be the 'most important' new supplement in 20 years. Available at: http://www.businessinsider.com/what-are-probiotics-what-do-they-do-health-2017-8. Erişim Tarihi: 23.07.2018.

Civelek I, Karabulut G, Mehmetoğlu AC (2017). Determination of antifungal effect of edible coatings containing Williopsis saturnus var. saturnus against yeast and mold growth on Kashar cheese. Journal of Microbial and Biochemical Technology 9 (6): 82-82.

Coma V, MartiaL-Gros A, Garreau S, Copinet A, Salin F and Deschamps A (2002). Edible antimicrobial films based on chitosan matrix. Journal of Food Science 67 (3): 1162-1169.

Concha-Meyer A, Schöbitz R, Brito C, Fuentes R (2011). Lactic acid bacteria in an alginate film inhibit Listeria monocytogenes growth on smoked salmon. Food Control 22 (3): 485-489.

Ebrahimi B, Mohammadi R., Rouhi M, Mortazavian AM, Shojaee-Aliabadi S, Koushki MR (2018). Survival of probiotic bacteria in carboxymethyl cellulose-based edible film and assessment of quality parameters. LWT - Food Science and Technology 87: 54-60.

Fan Y, Xu Y, Wang D, Zhang L, Sun J, Sun L, Zhang B (2009). Effect of alginate coating combined with yeast antagonist on strawberry (Fragaria ananassa) preservation quality. Postharvest Biology and Technology 53 (1): 84-90.

FAO/WHO (2002). Guidelines for the evaluation of probiotics in food. Report of a joint FAO/WHO working group on drafting guidelines for the evaluation of probiotics in food. London, Ont., Canada.

Galus S, Kadzińska J (2015). Food applications of emulsion-based edible films and coatings. Trends in Food Science and Technology 45 (2): 273-283.

Gerard P, Leyland P (1996). Packaging, marketing, logistics and the environment: are there trade-offs International Journal of Physical Distribution and Logistics Management 26 (6): 60-72.

Gialamas H, Zinoviadou KG, Biliaderis CG, Koutsoumanis KP (2010). Development of a novel bioactive packaging based on the incorporation of Lactobacillus sakei into sodium-caseinate films for controlling Listeria monocytogenes in foods. Food Research International 43 (10): 2402-2408.

Gontard N, Guilbert S (1994). "Bio-packaging: technology and properties of edible and/or biodegradable material of agricultural origin," in Food Packaging and Preservation, Mathlouthi, M., Ed., ed Boston, MA: Springer US, pp. 159-181. 
González-Estrada R, Calderón-Santoyo M, Carvajal-Millan E, Valle F, Ragazzo-Sánchez J, Brown-Bojorquez F, Rascón-Chu A (2015). Covalently cross-linked arabinoxylans films for Debaryomyces hansenii entrapment. Molecules 20 (6): 11373.

González-Estrada RR., Carvajal-Millán E, Ragazzo-Sánchez JA, Bautista-Rosales PU, Calderón-Santoyo M (2017). Control of blue mold decay on Persian lime: Application of covalently cross-linked arabinoxylans bioactive coatings with antagonistic yeast entrapped. LWT - Food Science and Technology 85: 187-196.

Granato D, Branco GF, Cruz AG, Faria JAF, Nazzaro F (2010). Functional foods and nondairy probiotic food development: Trends, concepts and products. Comprehensive Reviews in Food Science and Food Safety 9: 292-302.

Guimarães A, Abrunhosa L, Pastrana ML, Cerqueira AM (2018). Edible films and coatings as carriers of living microorganisms: A new strategy towards biopreservation and healthier foods. Comprehensive Reviews in Food Science and Food Safety 17 (3): 594-614.

Han JH (2014). "Edible films and coatings: A review," in Innovations in Food Packaging (Second Edition), Han, J. H., Ed., ed San Diego: Academic Press pp. 213-255.

Hassan B, Chatha SAS, Hussain AL, Pastrana ML, Zia KM, Akhtar N (2018). Recent advances on polysaccharides, lipids and protein based edible films and coatings: A review. International Journal of Biological Macromolecules 109: 1095-1107.

Jack RW, Tagg JR, Ray B (1995). Bacteriocins of gram-positive bacteria. Microbiological Reviews 59 (2): 171-200.

Kanmani P, Lim ST (2013). Development and characterization of novel probiotic-residing pullulan/starch edible films. Food Chemistry 141 (2): 1041-1049.

Karabulut G, Çağr1-Mehmetoğlu A (2018). Antifungal, mechanical, and physical properties of edible film containing Williopsis saturnus var. saturnus antagonistic yeast. Journal of Food Science 83 (3): 763-769.

Kołozyn-Krajewskaa D, Dolatowski ZJ (2012). Probiotic meat products and human nutrition. Process Biochemistry (Barking, London, England) 47: 1761-1772.

Krochta JM, De Mulder-Johnston C (1997). Edible and biodegradable polymer films: challenges and opportunities. Scientific Status Summary 51 (2): 61-74.

Krochta JM (2002). "Proteins as raw materials for films and coatings: Definitions, current status, and opportunities," in Protein Based Films and Coatings, Gennadios, A., Ed., ed Boca Raton, FL: CRC Press, pp. 1-41.

Liu J. Sui Y, Wisniewski M, Droby S, Liu Y (2013). Review: Utilization of antagonistic yeasts to manage postharvest fungal diseases of fruit. International Journal of Food Microbiology 167 (2): 153-160.

López de Lacey AM, López-Caballero ME, Gómez-Estaca J, Gómez-Guillén MC, Montero P (2012). Functionality of Lactobacillus acidophilus and Bifidobacterium bifidum incorporated to edible coatings and films. Innovative Food Science and Emerging Technologies 16: 277-282.

Marín A, Atarés L, Cháfer M, Chiralt A (2017). Properties of biopolymer dispersions and films used as carriers of the biocontrol agent Candida sake CPA-1. LWT - Food Science and Technology 79: 60-69.

Marín A, Cháfer M, Atarés L, Chiralt A, Torres R, Usall J, Teixidó N (2016). Effect of different coating-forming agents on the efficacy of the biocontrol agent Candida sake CPA-1 for control of Botrytis cinerea on grapes. Biological Control 96: 108-119.

McGuire RG, Baldwin EA (1994). Compositions of cellulose coatings affect populations of yeasts in the liquid formulation and on coated grapefruits. Proceedings of the Florida State Horticultural Society 107: 293-296.

McGuire RG, Dimitroglou DA (1999). Evaluation of shellac and sucrose ester fruit coating formulations that support biological control of post-harvest grapefruit decay. Biocontrol Science and Technology 9 (1): 53-65.

McGuire RG, Hagenmaier RD (1996). Shellac coatings for grapefruits that favor biological control of Penicillium digitatum by Candida oleophila. Biological Control 7 (1): 100-106.

Meng XH, Qin GZ, Tian SP (2010). Influences of preharvest spraying Cryptococcus laurentii combined with postharvest chitosan coating on postharvest diseases and quality of table grapes in storage. LWT - Food Science and Technology 43 (4): 596-601.

Moayednia N, Ehsani MR, Emamdjomeh Z, Asadi MM, Mizani M, Mazaheri AF (2009). The effect of sodium alginate concentrations on viability of immobilized Lactobacillus acidophilus in fruit alginate coating during refrigerator storage. Journal Australian Journal of Basic and Applied Sciences 3 (4): 3213-3216.

Morales-Ortega A, Carvajal-Millan E, Brown-Bojorquez F, Rascón-Chu A, Torres-Chavez P, López-Franco Y, Lizardi-Mendoza J, Martínez-López A, Campa-Mada A (2014). Entrapment of probiotics in water extractable arabinoxylan gels: rheological and microstructural characterization. Molecules 19 (3): 3628.

Nur Hanani ZA, Roos Y H, Kerry JP (2014). Use and application of gelatin as potential biodegradable packaging materials for food products. International Journal of Biological Macromolecules 71: 94-102.

Odila Pereira J, Soares J, Sousa S, Madureira AR, Gomes A, Pintado M (2016). Edible films as carrier for lactic acid bacteria. LWT - Food Science and Technology 73: 543-550.

Olivas GI, Barbosa-Cánovas GV (2005). Edible coatings for fresh-cut fruits. Critical Reviews in Food Science and Nutrition 45 (7-8): 657-670.

Oregel-Zamudio E, Angoa-Pérez MV, Oyoque-Salcedo G, Aguilar-González CN, Mena-Violante HG (2017). Effect of candelilla wax edible coatings combined with biocontrol bacteria on strawberry quality during the shelflife. Scientia Horticulturae 214: 273-279. 
Otoni CG, Avena-Bustillos RJ, Azeredo HMC, Lorevice MV, Moura MR, Mattoso LHC, McHugh TH (2017). Recent advances on edible films based on fruits and vegetables-A review. Comprehensive Reviews in Food Science and Food Safety 16 (5): 1151-1169.

Parafati L, Vitale A, Restuccia C, Cirvilleri G (2016). The effect of locust bean gum (LBG)-based edible coatings carrying biocontrol yeasts against Penicillium digitatum and Penicillium italicum causal agents of postharvest decay of mandarin fruit. Food Microbiology 58: 87-94.

Pareta, R., Edirisinghe, M., 2006. A novel method for the preparation of starch films and coatings. Carbohydrate Polymers 63 (3): 425-431.

Piermaria J, Diosma G, Aquino C, Garrote G, Abraham A (2015). Edible kefiran films as vehicle for probiotic microorganisms. Innovative Food Science \& Emerging Technologies 32: 193-199.

Polat, H., 2007. İşlenmiş Et Ürünlerinde Yenilebilir Filmler ve Kaplamaların Uygulamaları. Afyon Kocatepe Üniversitesi, Yüksek Lisans Tezi, Afyonkarahisar.

Potjewijd R, Nisperos MO, Burns JK, Parish M, Baldwin EA (1995). Cellulose-based coatings as carriers for Candida guillermondii and Debaryomyces sp. in reducing decay of oranges. HortScience 30 (7): 1417-1421.

Prado FC, Parada JL, Pandey A, Soccol CR (2008). Trends in non-dairy probiotic beverages. Food Research International 41 (2): 111-123.

Ray RC, Sivakumar PS (2009). Traditional and novel fermented foods and beverages from tropical root and tuber crops: review. International Journal of Food Science and Technology 44 (6): 1073-1087.

Romano N, Tavera-Quiroz MJ, Bertola N, Mobili P, Pinotti A, Gómez-Zavaglia A (2014). Edible methylcellulosebased films containing fructo-oligosaccharides as vehicles for lactic acid bacteria. Food Research International 64: 560-566.

Sánchez-González L, Quintero Saavedra JI, Chiralt A (2014). Antilisterial and physical properties of biopolymer films containing lactic acid bacteria. Food Control 35 (1): 200-206.

Santacruz S, Castro M (2018). Viability of free and encapsulated Lactobacillus acidophilus incorporated to cassava starch edible films and its application to Manaba fresh white cheese. LWT -Food Science and Technology 93: 570-572.

Sharma N, Verma U, Awasthi P (2006). A combination of the yeast Candida utilis and chitosan controls fruit rot in tomato caused by Alternaria alternata (Fr.) Keissler and Geotrichum candidum Link ex Pers. The Journal of Horticultural Science and Biotechnology 81 (6): 1043-1051.

Shigematsu E, Dorta C, Rodrigues FJ, Cedran MF, Giannoni JA, Oshiiwa M, Mauro MA (2018). Edible coating with probiotic as a quality factor for minimally processed carrots. Journal of Food Science and Technology 55(9): 3712-3720.

Skurtys O, Acevedo C, Pedreschi F, Enronoe J, Osorio F, Aguilera J (2014). Food hydrocolloid edible films and coatings. Nova Science Publishers, Incorporated.

Snoeijer, J. H., Ziegler, J., Andreotti, B., Fermigier, M., Eggers, J., 2008. Thick films of viscous fluid coating a plate withdrawn from a liquid reservoir. Physical Review Letters 100 (24): 244502.

Sothornvit R, Krochta JM (2005). "23 - Plasticizers in edible films and coatings," in Innovations in Food Packaging, Han, J. H., Ed., ed London: Academic Press pp. 403-433.

Soukoulis C, Behboudi-Jobbehdar S, Macnaughtan W, Parmenter C, Fisk ID (2017). Stability of Lactobacillus rhamnosus GG incorporated in edible films: Impact of anionic biopolymers and whey protein concentrate. Food Hydrocolloids 70: 345-355.

Soukoulis C, Behboudi-Jobbehdar S, Yonekura L, Parmenter C, Fisk ID (2014a). Stability of Lactobacillus rhamnosus GG in prebiotic edible films. Food Chemistry 159: 302-308.

Soukoulis C, Singh P, Macnaughtan W, Parmenter C, Fisk ID (2016). Compositional and physicochemical factors governing the viability of Lactobacillus rhamnosus GG embedded in starch-protein based edible films. Food Hydrocolloids 52: 876-887.

Soukoulis C, Yonekura L, Gan HH, Behboudi-Jobbehdar S, Parmenter C, Fisk I (2014b). Probiotic edible films as a new strategy for developing functional bakery products: The case of pan bread. Food Hydrocolloids 39: 231242.

Tapia MS, Rojas-Graü MA, Rodríguez FJ, Ramírez J, Carmona A, Martin-Belloso O (2007). Alginate- and gellanbased edible films for probiotic coatings on fresh-cut fruits. Journal of Food Science 72 (4): E190-E196.

Tavera-Quiroz MJ, Romano N, Mobili P, Pinotti A, Gómez-Zavaglia A, Bertola N (2015). Green apple baked snacks functionalized with edible coatings of methylcellulose containing Lactobacillus plantarum. Journal of Functional Foods 16: 164-173.

Tural S, Sarıcaoğlu FT, Turhan S (2017). Yenilebilir film ve kaplamalar: Üretimleri, uygulama yöntemleri, fonksiyonları ve kaslı gidalarda kullanımları. Akademik Gıda 15 (1): 84-94.

Vargas M, Albors A, Chiralt A, González-Martínez C (2006). Quality of cold-stored strawberries as affected by chitosan-oleic acid edible coatings. Postharvest Biology and Technology 41 (2): 164-171.

Vargas M, Pastor C, Chiralt A, McClements DJ, González-Martínez C (2008). Recent advances in edible coatings for fresh and minimally processed fruits. Critical Reviews in Food Science and Nutrition 48 (6): 496-511.

Yinzhe R., Shaoying Z (2013). Effect of carboxymethyl cellulose and alginate coating combined with brewer yeast on postharvest grape preservation. ISRN Agronomy 2013: pp. 1-7. 